\title{
Condition of Gobius cobitis (Pallas, 1811 ) juveniles in the Mar Menor coastal lagoon (SE Iberian Peninsula): Effects of inter- and intraspecific fish competition
}

\author{
DAVID VERDIELL-CUBEDO ${ }^{1}$, FRANCISCO J. OLIVA-PATERNA and MAR TORRALVA \\ Department of Zoology, University of Murcia, 30100 Murcia, Spain. E-mail: verdiell@um.es
}

\begin{abstract}
SUMMARY: We investigated the relationships, at a local level, between fish condition and environmental variables in Gobius cobitis juveniles. The relationships between 14 ecological variables of shallow areas of the Mar Menor coastal lagoon (water temperature, water salinity, depth, submerged vegetation richness, submerged vegetation cover, submerged vegetation volume, substrate size, substrate heterogeneity, fish species richness, potential competitor fish species abundance and biomass, G. cobitis abundance and biomass, G. cobitis biomass/abundance ratio) and fish condition were analysed. The mass-length relationship of juveniles was used to test differences in fish condition between 12 sampling sites. The ecological variables that accounted for most of the variation in fish condition were related to both inter- and intraspecific fish competition.
\end{abstract}

Keywords: somatic condition, mass-length relationship, environmental assessment, fish competition effects.

RESUMEN: Estado de CONDición de los JUVENILES de Gobius Cobitis (PAllas, 1811) en la laguna Costera del MaR MENOR (SE PENÍNSUla IBÉRICA): EFECTOS DE LA COMPETENCIA INTER- E INTRAESPECÍFICA EN PECES. - Se investigaron las relaciones, a nivel de localidad, entre el estado de condición de los juveniles de Gobius cobitis y las variables del hábitat. Fueron analizadas las relaciones entre 14 variables del habitat de las zonas someras de la laguna costera del Mar Menor (temperatura del agua, salinidad, profundidad, riqueza de especies de vegetación subacuática, cobertura de la vegetación subacuática, volumen de la vegetación subacuática, granulometría del sustrato, heterogeneidad del sustrato, riqueza de especies de peces, abundancia y biomasa de especies potencialmente competidoras, abundancia y biomasa de G. cobitis, relación biomasa/abundancia de G. cobitis) y el estado de condición de los peces. Las relaciones peso-longitud de los juveniles fueron utilizadas para testar las diferencias en el estado de condición de los peces entre las 12 localidades de muestreo. Las variables del habitat que explicaron la mayor variación en la condición fueron variables relacionadas con la competencia inter- e intraespecífica en peces.

Palabras clave: estado de condición, relación longitud-peso, variables del hábitat, competencia intra- e interespecífica.

\section{INTRODUCTION}

The geographical distribution range of Gobius cobitis (Pallas, 1811) is from the Atlantic coast of the western English Channel to Morocco, the Mediterranean and Black Sea. It lives in rocky-shallow pools of intertidal areas, and is common in estuaries and coastal lagoons. Its food preys are green algae, crustaceans, polychaetes and insects (Miller, 1986). Several authors have described its biology and habitat preferences (Gibson, 1970; Wheeler,
1993; Faria et al., 1998; Faria and Almada, 2001) but only for the Atlantic coastal areas of Europe. The species is a benthic resident fish in the Mar Menor coastal lagoon, where adults of this species preferentially occupy rocky substrata and juveniles sandy bottoms and mixed meadows of Caulerpa prolifera and Cymodocea nodosa (Barcala, 1999).

Gobies are an important component of fish assemblages in temperate estuaries and coastal lagoons (Arruda et al., 1993; Salgado et al., 2004). In terms of abundance and biomass, both larval and 
adult gobies are dominant in fish assemblages in the Mar Menor (Pérez-Ruzafa et al., 2004). However, few studies exist on the biology and ecology of these species in the western Mediterranean, and these studies are even scarce in the case of G. cobitis.

It is common to analyse fish condition for managing fish populations, as a measure of individual, cohort (e.g. age or size group) and population fitness (Jakob et al., 1996). These measurements are generally intended to be indicators of tissue energy reserves and may characterise components of the environment in which the fish live (e.g. food and habitat availability, competition, predation, physical factors, parasitic infections and pollution) (Bergeron, 2000; Copp, 2003; Lloret and Planes, 2003; Oliva-Paterna et al., 2003). A low body condition can negatively affect growth, survival, first maturity and reproductive effort in subsequent phases of the fish's life history (Marteinsdottir and Begg, 2002; Rätz and Lloret, 2003; Hoey and McCormick, 2004; Morgan, 2004).

For this reason, studying fish condition together with researching the habitat characteristics, will lead to a better understanding of the biology and ecology of fish populations. Moreover, fish condition indices are potential indicators that can be used to asses habitat quality in marine ecosystems such as coastal lagoons and estuaries (Lloret et al., 2005).

The purpose of this paper is to examine spatial variations in condition, estimated from the masslength relationship, of G. cobitis juveniles. More specifically, our aim is to study the potential influence of environmental variables (physico-chemical and biological parameters) on G. cobitis juveniles.

\section{MATERIALS AND METHODS}

\section{Study area}

The Mar Menor is a hypersaline coastal lagoon located in a semiarid region in the south-east of the Iberian Peninsula (Fig. 1). It is one of the largest coastal lagoons in the Mediterranean region and Europe, with a surface area of $135 \mathrm{~km}^{2}$ and an average depth of 3-4 m. It is separated from the Mediterranean Sea by a $22 \mathrm{~km}-$ long sand bar with three narrow channels connecting it with the open sea. The lagoon has a salinity range of 39-45 and the temperature varies from $10^{\circ} \mathrm{C}$ in winter to $32^{\circ} \mathrm{C}$ in summer. Its bottom is mainly covered by dense meadows of the invasive macroalga Caulerpa pro-

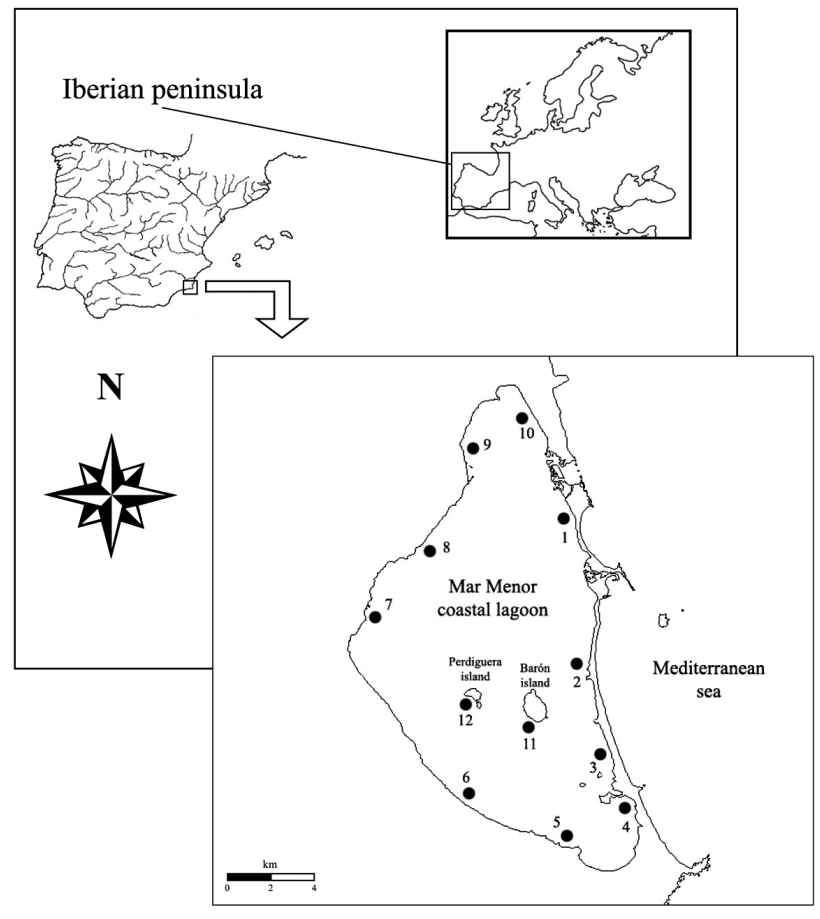

FIG. 1. - Geographical location of the Mar Menor coastal lagoon and location of sampling sites.

lifera, although shallow areas are covered by meadows of Cymodocea nodosa (Pérez-Ruzafa et al., 2002). The lagoon contains four inner volcanic islands: Perdiguera, Barón, Sujeto and Rondella.

Since the 1970s the Mar Menor has undergone large environmental changes following the widening of the connecting channels which caused a decrease in salinity from 50-52 to the present levels. Moreover, regular and intermittent watercourses flow into the lagoon, draining a large intensive agricultural area and leading to a significant input of agrochemicals (Pérez-Ruzafa et al., 2000; 2002). Finally, the Mar Menor coastal lagoon supports important commercial fisheries and is subject to intensive tourist development (Andreu-Soler et al., 2003).

Sampling sites are located in littoral and shallow areas (maximum depth $\leq 100 \mathrm{~cm}$ ) of the lagoon. The bottoms are characterised by soft substrates (mainly muddy and sandy bottoms) and isolated patches of submerged vegetation (meadows of Caulerpa prolifera, meadows of Cymodocea nodosa and meadows of Acetabularia calyculus and filamentous algae).

\section{Sampling methods}

The catches were made during July 2004 as part of a wider study to examine effects of human activities on fish communities of the coastal lagoon. A 
total of 12 sampling sites were selected, ten in the shallow perimeter areas and two in shallow areas of the Perdiguera and Barón islands (Fig. 1). Samples were collected using a $10 \mathrm{~m}$-long bag seine net and $0.5 \mathrm{~mm}$ mesh size, which allowed juvenile fish and adults of small sized species to be collected. We collected three quantitative replicates at each sampling site by adjacent $20 \mathrm{~m}$ reaches of shoreline at each site. In each reach, the bag seine was hauled offshore parallel to the shoreline in water $<1.0 \mathrm{~m}$ for the whole length of the reach. The area covered by each haul was approximately $160 \mathrm{~m}^{2}$ (quantitative sampling).

Additional bag seine hauls and quadrangular $(40 \times 40 \mathrm{~cm}$ ) hand net sweeps (non-quantitative samplings) were made along the shoreline in each sampling area. Our goal was to sample all shoreline habitats to detect species richness in a given sampling site.

Thus, four replicate samples ( 3 quantitative and 1 non-quantitative) were obtained at each of the 12 sampling sites, enabling us to assess variance within sites and the efficiency of seining.

Fish from each of the three reaches (quantitative samplings) and non-quantitative samplings were preserved in separate jars in $7 \%$ formaldehyde before being removed and identified at species level in the laboratory (Whitehead et al., 1986; Arias and Drake, 1990).

Relative abundance was expressed as catch per unit effort (CPUEs) and biomass per unit effort (BPUEs):

CPUEs $=$ fish number $/$ haul area covered $\left(160 \mathrm{~m}^{2}\right)$
BPUEs $=$ fish biomass $(\mathrm{g}) /$ haul area covered $\left(160 \mathrm{~m}^{2}\right)$

A total of 385 juvenile individuals of $G$. cobitis (with total lengths ranging from 23 to $60 \mathrm{~mm}$ ) from twelve sampling sites were measured for total length $(\mathrm{TL}, \pm 1 \mathrm{~mm})$ and total mass $(\mathrm{TM}, \pm 0.01 \mathrm{~g})$. Fish larger than $60 \mathrm{~mm}$ (non-juveniles sensu Faria and Almada (2001)) were excluded from the analysis to avoid possible differences in body shape between juveniles and adults (Murphy et al., 1990).

Each sampling site was characterised by 14 environmental variables and indices (quantified in each reach of every sampling site) related to water quality (weekly mean values), habitat structure (local level), possible resources exploited by fish populations and intra and interspecific interactions: water temperature $\left({ }^{\circ} \mathrm{C}\right)$, water salinity, depth $(\mathrm{cm})$, submerged vegetation species richness, submerged vegetation cover (\%), submerged vegetation volume, substrate size, substrate heterogeneity, fish species richness, potential competitor fish species abundance and biomass, G. cobitis abundance, G. cobitis biomass and $G$. cobitis biomass/abundance ratio (Table 1).

We identified four main types of submerged vegetation: meadows of Caulerpa, meadows of Cymodocea, meadows of Acetabularia and filamentous algae (mainly Cladophora and Chaetomorpha). Submerged vegetation cover (0-100\%) was assessed by an average value at each sampling site. Submerged vegetation volume was classified as an ordinate categorical variable from 0 (low density of meadows) to 5 (high density of meadows). We clas-

TABLE 1. - Environmental variables in each sampling site. Water temperature; Water salinity; Depth; Submerged vegetation species richness; Submerged vegetation cover; Submerged vegetation volume: 0 (low density) to 5 (high density); Substrate size (SS; mean value); Substrate heterogeneity (SH; mean value); Fish species richness; Potential competitors fish species abundance; Potential competitor fish species biomass; G. cobitis abundance; G. cobitis biomass; G. cobitis B/A ratio.

\begin{tabular}{|c|c|c|c|c|c|c|c|c|c|c|c|c|c|c|}
\hline Sampling site & $\begin{array}{l}\text { Water } \\
\text { temperature } \\
\left({ }^{\circ} \mathrm{C}\right)\end{array}$ & Salinity & $\begin{array}{c}\text { Depth } \\
\text { (cm) }\end{array}$ & $\begin{array}{c}\text { Submerged } \\
\text { vegetation } \\
\text { richness }\end{array}$ & $\begin{array}{c}\text { Submerged } \\
\text { vegetation } \\
\text { cover }(\%)\end{array}$ & $\begin{array}{c}\text { Submerged } \\
\text { vegetation } \\
\text { volume }\end{array}$ & SS & SH & $\begin{array}{c}\text { Fish } \\
\text { species } \\
\text { richness }\end{array}$ & $\begin{array}{l}\text { Potential } \\
\text { competitor } \\
\text { fish species } \\
\text { abundance } \\
\text { (CPUEs) }\end{array}$ & $\begin{array}{l}\text { Potential } \\
\text { competitor } \\
\text { fish species } \\
\text { biomass } \\
\text { (BPUEs) }\end{array}$ & $\begin{array}{c}\text { G. cobitis } \\
\text { abundance } \\
\text { (CPUEs) }\end{array}$ & $\begin{array}{l}\text { G. cobitis } \\
\text { biomass } \\
\text { (BPUEs) }\end{array}$ & $\begin{array}{c}\text { G. cobitis } \\
\text { B/A } \\
\text { ratio }\end{array}$ \\
\hline Encañizadas (1) & 27.8 & 43.5 & 61 & 1 & 63 & 3.2 & 2.1 & 0.4 & 14 & 115.0 & 29.8 & 1.0 & 0.2 & 0.23 \\
\hline Las Brisas (2) & 27.0 & 43.9 & 58 & 2 & 28 & 2.3 & 2.5 & 0.8 & 14 & 132.7 & 48.5 & 14.3 & 7.7 & 0.54 \\
\hline Los Alíseos (3) & 26.7 & 43.9 & 72 & 1 & 43 & 1.7 & 2.3 & 0.5 & 11 & 127.0 & 33.4 & 4.7 & 3.1 & 0.67 \\
\hline El Ciervo(4) & 28.8 & 43.9 & 52 & 1 & 7 & 0.7 & 2.3 & 0.6 & 8 & 206.3 & 26.4 & 3.0 & 2.5 & 0.84 \\
\hline Playa Paraiso (5) & 25.9 & 44.7 & 56 & 3 & 33 & 1.8 & 2.7 & 0.7 & 11 & 363.3 & 70.3 & 13.7 & 10.5 & 0.77 \\
\hline Lo Poyo (6) & 29.5 & 44.2 & 39 & 2 & 45 & 2.0 & 2.3 & 1.0 & 10 & 68.3 & 37.7 & 45.0 & 30.7 & 0.68 \\
\hline La Hita (7) & 29.9 & 44.0 & 62 & 2 & 17 & 1.0 & 2.3 & 0.9 & 9 & 122.6 & 19.0 & 1.0 & 0.9 & 0.93 \\
\hline El Carrizal (8) & 29.7 & 43.5 & 44 & 2 & 80 & 4.5 & 2.2 & 1.1 & 7 & 247.0 & 94.9 & 0.5 & 0.9 & 0.80 \\
\hline San Pedro (9) & 26.1 & 43.5 & 59 & 3 & 80 & 3.3 & 1.9 & 0.7 & 11 & 133.3 & 38.4 & 9.3 & 25.6 & 2.75 \\
\hline La Calcetera (10) & 27.6 & 44.2 & 63 & 4 & 45 & 3.0 & 2.4 & 0.9 & 9 & 172.3 & 29.5 & 5.3 & 6.3 & 1.18 \\
\hline Barón island (11) & 28.2 & 45.1 & 95 & 3 & 90 & 4.0 & 3.1 & 0.7 & 10 & 9.0 & 19.6 & 9.3 & 26.0 & 2.79 \\
\hline Perdiguera island (12) & 28.3 & 45.0 & 56 & 1 & 23 & 1.0 & 2.2 & 0.4 & 12 & 179.0 & 38.3 & 5.3 & 14.6 & 2.73 \\
\hline
\end{tabular}


sified substrate sensu Bain (1999) [mud (1), sand (2), gravel (3), pebble (4) and boulder (5)] and assessed the substrate size (SS; average at each sampling site) and substrate heterogeneity ( $\mathrm{SH}$, standard deviation at each sampling site). Fish species richness was evaluated as the total number of fish species at each sampling site.

Pomatoschistus sp., Lipophrys dalmatinus, Salaria pavo, Diplodus sargus sargus, Gobius niger, Gobius paganellus, Callionymus pusillus and Symphodus cinereus were considered as potential competitor fish species due to their benthic habitat and carnivorous diet (Quignard and Pras, 1986; Dumay et al., 2004). In this way, potential competitor fishes and G. cobitis relative abundance and biomass were assessed as mean CPUEs and BPUEs respectively at each sampling site.

\section{Statistical analyses}

The statistical analysis used to compare fish condition was based on that used in previous studies (Vila-Gisbert and Moreno-Amich, 2001; OlivaPaterna et al., 2003) and proposed by GarcíaBerthou and Moreno-Amich (1993). The method applies univariate analysis of covariance (ANCOVA) using total mass as the dependent variable and total length as the covariate. The relationship between total mass and length was clearly non-linear, but was linear after log-transformation (ln). The homogeneity of the regression coefficients (slopes) was tested with an ANCOVA design that analysed the pooled covariate-by-factor interaction. If the covariate-by-factor interaction (homogeneity of slopes) was not significant $(\mathrm{P}>0.05)$, standard ANCOVA was applied to test differences in the parameter $a$ (the $y$-intercept) between sampling sites.

A stepwise multiple regression analysis was performed to determine the amount of variation in parameter $a$ (the $y$-intercept) associated with environmental variables. Colinearity between environmental variables included in the regression model was tested using Tolerance Index (TI) (VisautaVinacua, 1997).

To explore patterns of association among the environmental variables of the 12 sampling sites, principal component analysis (PCA) was applied to the correlation matrix. A varimax rotation of the resulting matrix was performed (Visauta-Vinacua, 1997).

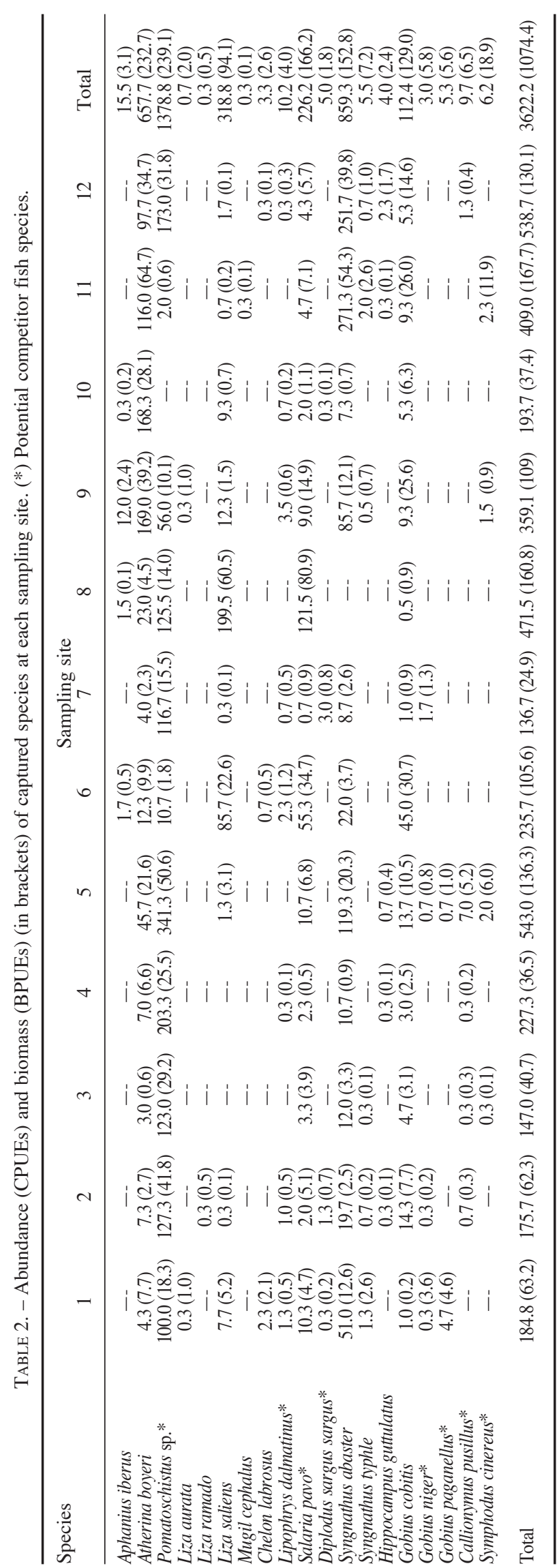


TABLE 3. - Regression coefficients $(a, b) \pm$ S.D. and correlation coefficients (r) of the ln-transformed mass-length relationship.

\begin{tabular}{|c|c|c|c|c|c|}
\hline Sampling site & $\mathrm{n}$ & b (slope) & a (the $y$-intercept) & Adjusted $r^{2}$ & Mean \pm S.D. of TL \\
\hline Encañizadas (1) & 15 & $2.88 \pm 0.12$ & $-17.11 \pm 0.96$ & 0.98 & $3.6 \pm 0.4$ \\
\hline Las Brisas (2) & 46 & $2.98 \pm 0.09$ & $-17.99 \pm 0.70$ & 0.96 & $3.2 \pm 0.6$ \\
\hline Los Alíseos (3) & 23 & $2.99 \pm 0.07$ & $-18.13 \pm 0.53$ & 0.99 & $3.5 \pm 0.7$ \\
\hline El Ciervo (4) & 14 & $3.09 \pm 0.13$ & $-18.88 \pm 1.01$ & 0.98 & $4.0 \pm 0.6$ \\
\hline Playa Paraíso (5) & 35 & $3.18 \pm 0.06$ & $-19.63 \pm 0.51$ & 0.99 & $3.7 \pm 0.7$ \\
\hline Lo Poyo (6) & 133 & $3.06 \pm 0.04$ & $-18.65 \pm 0.36$ & 0.97 & $3.5 \pm 0.6$ \\
\hline La Hita (7) & 19 & $2.96 \pm 0.07$ & $-17.72 \pm 0.53$ & 0.99 & $3.3 \pm 0.8$ \\
\hline El Carrizal (8) & 19 & $3.17 \pm 0.21$ & $-19.50 \pm 1.77$ & 0.97 & $5.2 \pm 0.7$ \\
\hline San Pedro (9) & 17 & $3.18 \pm 0.06$ & $-19.56 \pm 0.50$ & 0.99 & $4.8 \pm 0.7$ \\
\hline La Calcetera (10) & 18 & $3.10 \pm 0.09$ & $-18.94 \pm 0.74$ & 0.99 & $4.4 \pm 0.5$ \\
\hline Barón Island (11) & 27 & $2.99 \pm 0.09$ & $-18.01 \pm 0.78$ & 0.98 & $3.9 \pm 0.6$ \\
\hline Perdiguera Island (12) & 19 & $3.18 \pm 0.09$ & $-19.53 \pm 0.78$ & 0.99 & $5.0 \pm 0.7$ \\
\hline
\end{tabular}

Statistical analyses were performed with the SPSS ${ }^{\circledR}$ software package and a significance level of $\mathrm{P} \leq 0.05$ was accepted.

\section{RESULTS}

Fish community structure varied considerably across the 12 sampling sites. Of the 19 taxa captured (Table 2), Pomatoschistus sp. (38.1\% of total captures), Syngnathus abaster (23.7\% of total captures) and Atherina boyeri ( $18.2 \%$ of total captures) were the most abundant species. In turn, the dominant species in biomass terms were Pomatoschistus sp. (22.3\% of total biomass), A. boyeri (21.7\% of total biomass) and Salaria pavo (15.5\% of total biomass). G. cobitis accounted for $3.1 \%$ of the total abundance and $12.0 \%$ of the total biomass.

Potential competitor fish species represented $45.0 \%$ of the total abundance and $42.0 \%$ of the total biomass (Table 2).
TABLE 4. - ANCOVA analyses of the mass-length relationship in $G$. cobitis. All variables (dependent and covariate) were ln-transformed. Total length is the covariate.

\begin{tabular}{lccc}
\hline Source of variation & F & d.f. & P \\
\hline Preliminary design (test for interaction) & & \\
TL & 7161.79 & 1.384 & $<0.0005$ \\
Sampling site & 0.865 & 11.384 & 0.575 \\
TL x Sampling site & 0.879 & 11.384 & 0.561 \\
Final design (no interaction) & & & \\
TL & 15417.02 & 1.384 & $<0.0005$ \\
Sampling site & 4.06 & 11.384 & $<0.0005$ \\
& & & \\
\hline
\end{tabular}

Coefficients of the mass-length relationship of sampling sites are presented in Table 3 and the results of the ANCOVA are shown in Table 4. There was significant homogeneity $(\mathrm{P}=0.561)$ between sampling sites on the slope (parameter $b$ ) of the TMTL relationships (Preliminary design, Table 4), although the y-intercept (parameter $a$ ) varied significantly $(\mathrm{P}<0.0005)$ between sampling sites (Final

TABLE 5. - Stepwise multiple regression model used to predict coefficient a of the mass-length relationship from environmental variables.

\begin{tabular}{|c|c|c|c|c|c|}
\hline Environmental variables & Regression equations & Adjusted $r^{2}$ & $\mathrm{~F}$ & d.f. & $\mathrm{P}$ \\
\hline $\begin{array}{l}\text { Model } 1 \\
\text { Potential competitor fish } \\
\text { species abundance (CPUEs) }\end{array}$ & $\begin{array}{l}a=-17.73-0.621 \text { (potential } \\
\text { competitor fish species abundance) }\end{array}$ & 0.324 & 6.264 & 1,10 & $<0.05$ \\
\hline $\begin{array}{l}\text { Model } 2 \\
\text { Potential competitor fish } \\
\text { species abundance (CPUEs) } \\
\text { Biomass/abundance ratio of } \\
\text { G. cobitis }\end{array}$ & $\begin{array}{l}a=-16.849-0.727 \text { (potential } \\
\text { competitor fish species abundance) - } \\
0.611 \text { (biomass/abundance ratio of } \\
\text { G. cobitis) }\end{array}$ & 0.691 & 13.322 & 2,9 & $<0.005$ \\
\hline $\begin{array}{l}\text { Model } 3 \\
\text { Potential competitor fish } \\
\text { species abundance (CPUEs) } \\
\text { Biomass/abundance ratio of } \\
\text { G. cobitis } \\
\text { Abundance of } G \text {. cobitis (CPUEs) }\end{array}$ & $\begin{array}{l}a=-16.326-0.838 \text { (potential competitor } \\
\text { fish species abundance) }-0.695 \text { (biomass/ } \\
\text { abundance ratio of G. cobitis) }-0.403 \\
\text { (abundance of } G . \text { cobitis) }\end{array}$ & 0.854 & 22.506 & 3,8 & $<0.005$ \\
\hline
\end{tabular}




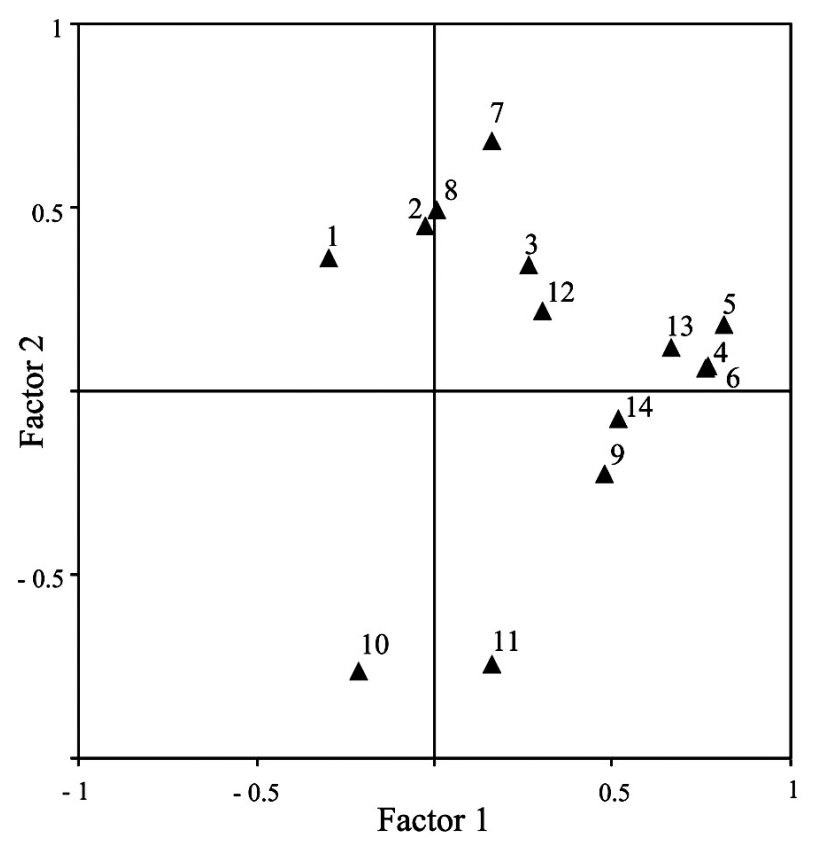

FIG. 2. - Result of the principal component analysis that includes environmental variables: 1 , water temperature; 2 , salinity; 3 , depth; 4 , submerged vegetation richness; 5 , submerged vegetation cover; 6 , submerged vegetation volume; 7 , substrate size; 8 , substrate heterogeneity; 9 , fish species richness; 10, potential competitor fish species abundance; 11 , potential competitor fish species biomass; $12, G$. cobitis abundance; $13, G$. cobitis biomass; $14, G$. cobitis B/A ratio.

design, Table 4). As a result, sampling sites could be compared according to the values of parameter $a$ of the TM-TL relationships. The Playa Paraiso (5) sampling site showed the lowest fish condition value, and Encañizadas (1) showed the highest fish condition value.

A stepwise multiple regression model indicated that potential competitor fish species abundance, the biomass/abundance ratio of $G$. cobitis and $G$. cobitis abundance accounted for most of the variation between sampling sites $(85.4 \%)$ of parameter $a$ in the TM-TL relationships (Table 5), and the condition of $G$. cobitis juveniles was effected negatively. The Tolerance Index value was 0.897, 0.927 and 0.901 respectively, showing no colinearity between environmental variables included in the regression model.

The first two factors extracted by PCA explained $40 \%$ of the total variance (factor 1,23.6\%; factor 2, 16.4\%). Inspection of Fig. 2 supports the following conclusions: there was a high level of association between the first factor and submerged vegetation (richness, cover and volume). Secondly, potential competitor fish species abundance and potential competitor fish species biomass were strongly associated with factor 2 .
It is worth pointing out the strong association between variables related to submerged vegetation and the G. cobitis biomass/abundance ratio.

\section{DISCUSSION}

In the investigation of intra- and interpopulation variations in fish condition, mass-length regressions provide a good alternative to relative mass indices (ratio-related techniques), assuming that the slope does not vary between nearby sampling sites or that the slope is homogeneous for population at a local level (Sutton et al., 2000). Relative mass indices do not normally fulfil these underlying assumptions, and have been criticised on statistical grounds (Jakob et al., 1996). In fact, adjusting size variation in the data by regression-related techniques has been used with the ANCOVA approach providing valid results (Vila-Gisbert and Moreno-Amich, 2001; Oliva-Paterna et al., 2003).

Our results showed that the condition of $G$. cobitis juveniles differed between the sampling sites studied. Any differences in parameter $a$ of the TMTL relationship were probably caused by differences in ecological conditions. Although fish size could be an important factor affecting fish condition (Pope and Willis, 1996), the homogeneity of the slopes of the mass-length relationship obtained for the sampling sites studied indicated that condition was independent of fish body form (Winters and Wheeler, 1994). Moreover, the fact that the sampling period was short (July) and that the study focused on juvenile specimens ( $\mathrm{TL}<60 \mathrm{~mm}$ ), ensured that the differences in parameter $a$ of the TM-TL relationships were not related to seasonal variations in the condition of G. cobitis.

In our site level analysis of habitat-fish condition relationships, potential competitor fish, biomass/ abundance ratio of $G$. cobitis and abundance of $G$. cobitis (significant variables in the stepwise multiple regression analyses) were the ecological variables that best correlated with G. cobitis juvenile condition. Sampling sites with higher values of potential competitor fish abundance and higher biomass of G. cobitis (Playa Paraiso, El Carrizal, San Pedro and Perdiguera island) provided the lowest values for parameter $a$ of the TM-TL relationship, demonstrating a poorer juvenile fish condition.

Inter- and intraspecific competition can be an important factor influencing fish habitat selection, 
predation risk and fish condition. Several studies have shown that competitive superiority explains the higher condition of dominant fishes versus subordinate fishes (Rauch, 1996; Adams et al., 1998; Sloman et al., 2001). Moreover, several authors have remarked that habitat selection by gobies appears to be directly influenced by the presence of species of the same family and blenny species (Faria et al., 1998; Munday et al., 2001; Schofield, 2003). In sampling sites with a higher abundance of potential competitor fish species, it is very probable that there is a risk of aggression by territorial and larger individuals of Salaria pavo, Gobius niger and Gobius paganellus. Faria et al. (1998) demonstrated that juveniles of two species of blennies (Lipophrys pholis and Coryphoblennius galerita) dominated $G$. cobitis juveniles. Moreover, interspecific competition for limited refuge and/or for food resources may increase in microhabitats where similar sized individuals are abundant. In fact, Pomatoschistus sp. showed a significantly higher abundance and biomass (Table 1), which, due to the similarity in habitat and diet of this taxon (Salgado et al., 2004) and G. cobitis juveniles, could be an important interspecific competition factor as a result of trophic overlap. Hence, a high abundance of potential competitor fish species produces a significant level of stress in G. cobitis juveniles, which is reflected in a decrease of their somatic condition.

Previous studies in the Mar Menor coastal lagoon (Barcala, 1999) noted that smaller G. cobitis (juveniles) tended to inhabit sand banks and beds of Caulerpa prolifera where the presence of larger individuals of the same species is lower. However, in our study, there was a high association between submerged vegetation and the presence of larger individuals of $G$. cobitis.

It is possible that larger individuals monopolised refuges in the population (e.g. patches of submerged vegetation and shelter in the form of crevices and holes). In fact, the sampling sites presented a relatively low substrate size (sand-gravel), but high submerged vegetation cover, so these patches of submerged vegetation could offer an alternative refuge for larger individuals. Their competitive superiority may reduce the availability of fish refuges for smaller conspecifics, with the result that the dominant fishes show a higher condition value than subordinate fish.

In addition, intraspecific competition for food increases with increasing densities of individuals
(Heath, 1992). Cowan et al. (2000) concluded that, during the late-larval to juvenile stage, a reduction in prey resources due to high population densities is an important factor for cohort growth. Yuma et al. (2000) noticed that, in the absence of predators, Rhinogobius sp. juveniles increase agonistic interactions by competing for space and food. In the sampling sites which showed higher G. cobitis abundance, competition between juvenile fish for empty refuges and/or for food resources was particularly strong.

Spatial heterogeneity of the fish condition related to spatial differences in environmental conditions has also been found in other fish species (Rätz and Lloret, 2003; Lloret and Planes, 2003). Although the mobility of G. cobitis juveniles in the study area is poorly known, the spatial distribution of its larvae was related to hydrographical circulation patterns in the lagoon (Pérez-Ruzafa et al., 2004). It is probable that this benthic species has restricted mobility in the early phases of its life history (larvae and juvenile individuals) and, consequently, it might be impacted by the characteristics of the habitat.

We found no relationship between habitat structure and juvenile fish condition, probably due to the number of sampling sites or perhaps because any relationship was clouded by the large complexity of the ecological interactions (e.g. a non-linear relationship between these variables). To a certain extent, this demonstrates the need for more research into the relationships between habitat characteristics, environmental variations and juvenile fish condition in the study area.

In conclusion, the somatic condition of the early phases of the life history of G. cobitis (juvenile fishes) in the shallow areas of the Mar Menor coastal lagoon were affected by the potential competitor fish species, G. cobitis B/A ratio and G. cobitis abundance, which are probably related to both interand intraspecific competition. Shallow areas with a lower abundance of potential competitor fish species, lower presence of larger G. cobitis individuals and lower G. cobitis abundance produced juveniles with a better somatic condition because they may have mitigated competition events.

\section{ACKNOWLEDGEMENTS}

The authors are grateful to Asunción Andreu, Pedro A. Miñano, Andrés Egea and members of the Department of Zoology of the University of Murcia 
for help in field sampling; and Philip Thomas for the English revision. Part of this research was supported by the Environmental Service of the Autonomous Government of Murcia, Spain.

\section{REFERENCES}

Adams, C.E., F.A. Huntingford, J.F. Turnbull and C. Beattie. 1998 Alternative competitive strategies and the cost of food adquisition in juvenile Atlantic salmon (Salmo salar). Aquaculture, 167: 17-26.

Andreu-Soler, A., F.J. Oliva-Paterna, C. Fernández-Delgado and M. Torralva. - 2003 Age and growth of the sand smelt, Atherina boyeri (Risso 1810), in the Mar Menor coastal lagoon (SE Iberian Peninsula). J. Appl. Ichthyol., 19: 202-208.

Arias, A.M. and P. Drake.-1990. Estados alevines y juveniles de la ictiofauna en los caños de las salinas de la bahía de Cádiz. Instituto de Ciencias Marinas de Andalucía. CSIC. Junta de Andalucía.

Arruda, L.M., J.N. Azevedo and A.I. Neto. - 1993. Abundance, age-structure and growth, and reproduction of Gobies (Pisces; Gobiidae) in the Ria de Aveiro Lagoon (Portugal). Estuar. Coast. Shelf Sci., 37: 509-523.

Bain, M.B. - 1999. Substrate. In: M.B. Bain and N.J. Stevenson (eds.), Aquatic habitat assesment: common methods, pp. 95100. American Fisheries Society, Bethesda, Maryland.

Barcala, E. - 1999. Estudio ecológico de la fauna ictiológica del Mar Menor. Ph. D. thesis, Universidad de Murcia.

Bergeron, J.P. - 2000. Effect of strong winds on the nutritional condition of anchovy (Engraulis encrasicolus L.) larvae in the Bay of Biscay, Northeast Atlantic, as inferred from an early field application of the DNA/C index. ICES J. Mar. Sci., 57: 249-255.

Copp, G.H. - 2003. Is fish condition correlated with water conductivity? J. Fish Biol., 63: 263-266.

Cowan, J.H. Jr., K.A. Rose and D.R. DeVries. - 2000. Is densitydependent growth in young-of-the-year fishes a question of critical weight? Rev. Fish Biol. Fish., 10: 61-89.

Dumay, O., P.S. Tari, J.A. Tomasini and D. Mouillot. - 2004. Functional groups of lagoon fish species in Languedoc Roussillon, southern France. J. Fish Biol., 64: 970-983.

Faria, C., V. Almada and M.C. Nunes. - 1998. Patterns of agonistic behaviour, shelter occupation and habitat preference in juvenile Lipophrys pholis, Coryphoblennius galerita and Gobius cobitis. J. Fish Biol., 53: 1263-1273.

Faria, C. and V. Almada. - 2001. Microhabitat segregation in three rocky intertidal fish species in Portugal: does it reflect interspecific competition? J. Fish Biol., 58: 145-159.

García-Berthou, E. and R. Moreno-Amich. - 1993. Multivariate analysis of covariance in morphometric studies of the reproductive cycle. Can. J. Fish Aquat. Sci., 50: 1394-1399.

Gibson, R.N. - 1970. Observations on the biology of the giant goby Gobius cobitis. J. Fish Biol., 2: 281-288.

Heath, M.R. - 1992. Field investigations on the early life stages of marine fish. Adv. Mar. Biol., 28: 1-174.

Hoey, A.S. and M.I. McCormick. - 2004. Selective predation for low body condition at the larval-juvenile transition of a coral reef fish. Oecologia, 139: 23-29.

Jakob, E.M., S.D. Marshall and G.W. Uetz. - 1996. Estimating fitness: a comparasion of body condition indices. Oikos, 77: 61-67.

Lloret, J. and S. Planes. - 2003. Condition, feeding and reproductive potential of white seabream Diplodus sargus as indicators of habitat quality and the effect of reserve protection in the northwestern Mediterranean. Mar. Ecol. Prog. Ser., 248: 197-208.

Lloret, J., R. Galzin, L. Gil de Sola, A. Souplet and M. Demestre. 2005. Habitat related differences in lipid reserves of some xploited fish species in the north-western Mediterranean continental shelf. J. Fish Biol., 67: 51-65.

Marteinsdottir, G. and G.A. Begg. - 2002. Essential relationships incorporating the influence of age, size and condition on variables required for estimation of reproductive potential in Atlantic cod Gadus morhua. Mar. Ecol. Prog. Ser., 235: 235-256.
Miller, P.J. - 1986. Gobiidae. In: P.J.P. Whitehead, M.L. Bauchot, J.C. Hureau, J. Nielsen and E. Tortonese (eds.), Fishes of the North-eastern Atlantic and the Mediterranean vol. III., pp. 1019-1085. Unesco, Bungay.

Morgan, M.J. - 2004. The relatioship between fish condition and the probability of being mature in American plaice (Hippoglossoides platessoides). ICES J. Mar. Sci., 61: 64-70.

Munday, P.L., G.P. Jones and M.J. Caley. - 2001. Interspecific competition and coexistence in a guild of coral-dwelling fishes. Ecology, 82: 2177-2189.

Murphy, B.R., M.L. Brown and T.A. Springer. - 1990. Evaluation of the relative weight (Wr) Index, with new applications to walleye. North Am. J. Fish Man., 10: 85-97.

Oliva-Paterna, F.J., A. Vila-Gisbert and M. Torralva. - 2003. Condition of Barbus sclateri from semiarid aquatic systems: effects of habitat quality disturbances. J. Fish Biol., 63: 1-11.

Pérez-Ruzafa, A., S. Navarro, A. Barba, C. Marcos, M.A. Cámara, F. Salas and J.M. Gutiérrez. - 2000. Presence of pesticides troughout trophic compartments of the food web in the Mar Menor lagoon (SE Spain). Mar. Poll. Bull., 40: 140-151.

Pérez-Ruzafa, A., J. Gilabert, J.M. Gutiérrez, A.I. Fernández, C. Marcos and S. Sabah. - 2002. Evidence of a planktonic food web response to changes in nutrient input dynamics in the Mar Menor coastal lagoon, Spain. Hydrobiologia, 475/476: 359-369.

Pérez-Ruzafa, A., J.I. Quispe-Becerra, J.A. García-Charton and C. Marcos. - 2004. Composition, structure and distribution of the ichthyoplankton in a Mediterranean coastal lagoon. J. Fish Biol., 64: 202-218.

Pope, K.L. and D.W. Willis. - 1996. Seasonal influences on freshwater fisheries sampling data. Rev. Fish Sci., 4: 57-73.

Quignard, J.P. and A. Pras. - 1996. Labridae. In: P.J.P. Whitehead, M.L. Bauchot, J.C. Hureau, J. Nielsen and E. Tortonese (eds.), Fishes of the North-eastern Atlantic and the Mediterranean vol. III., pp. 919-942. Unesco, Bungay.

Rätz, H.J. and J. Lloret. - 2003. Variation in fish condition between Atlantic cod (Gadus morhua) stocks, the effect on their productivity and management implications. Fish. Res., 60: 369-380.

Rauch, T.J. - 1996. Effect of size and prior residence on dominance in male seaweed blennies, Parablenius marmoreus. Gulf Mex. Sci., 1666: 105-111.

Salgado, J.P., H. Nogueira-Cabral and M.J. Costa. - 2004. Feeding ecology of the gobies Pomatoschistus minutus (Pallas, 1770) and Pomatoschistus microps (Kroyer, 1838) in the upper Tagus stuary, Portugal. Sci. Mar., 68 (3): 425-434.

Schofield, P.J. - 2003. Habitat selection of two gobies (Microgobius gulosus, Gobiosoma robustum): influence of structural complexity, competitive interactions, and presence of a predator. J. Exp. Mar. Biol. Ecol., 288: 125-137.

Sloman, K.A, A.C. Taylor, N.B. Metcalfe and K.M. Gilmour. 2001. Effects of an environmental perturbation on the social behaviour and physiological function of brown trout. Anim. Behav., 61: 325-333.

Sutton, S.G., T.P. Bult and R.L. Haedrich. - 2000. Relationships among fat weight, body weight, water weight and condition factors in wild salmon parr. Trans. Am. Fish. Soc., 129: 527-538.

Vila-Gisbert, A. and R. Moreno-Amich. - 2001. Mass-lenght relationship of Mediterranean barbel as an indicator of environmental status in South-west European stream ecosystems. $J$. Fish Biol., 59: 824-832.

Visauta-Vinacua, B. - 1997. Análisis estadístico con SPSS para Windows. McGraw-Hill, Madrid.

Wheeler, A. - 1993. The distribution of Gobius cobitis in the British Isles. J. Fish Biol., 43: 652-655.

Whitehead, P.J.P., M.L. Bauchot, J.C. Hureau, J. Nielsen and E. Tortonese. - 1986. Fishes of the North-eastern Atlantic and the Mediterranean vol. III. Unesco, Bungay.

Winters, G.H. and J.P. Wheeler. - 1994. Lenght-specific weight as a mesure of growth success of adult Atlantic herring (Clupea harengus). Can. J. Fish Aquat. Sci., 51: 1169-1179.

Yuma, M., A. Maruyama and B. Rusuwa. - 2000. Behavior and distribution of upstream-migrating juvenile Rhinogobius sp. (the orange form). Icthyol. Res., 47: 379-384.

Scient. ed.: M. Harmelin-Vivien

Received May 4, 2005. Accepted October 11, 2005. 